\title{
STUDENTS' UNDERSTANDING OF AMBIGUOUS SENTENCES IN WEBSITES
}

\author{
Dennis; Ienneke Indra Dewi \\ Jurusan Sastra Inggris, Fakultas Bahasa dan Budaya, Bina Nusantara University \\ Jln. Kemanggisan Ilir III No. 45, Palmerah, Jakarta Barat 11480
}

\begin{abstract}
Article intended to find out the most frequent ambiguity that could be found in the sentences and the intended meaning. Data were taken from Kaskus and Facebook web sites, and then tests were given to students who had learned syntax and semantics to know their ability in noticing ambiguous sentences. The results show that there are among 13 sentences or phrases, 12 of them are lexically ambiguous and 1 sentence is structurally ambiguous. From the result, it can be concluded that there are many people making an ambiguous sentence without realizing it.
\end{abstract}

Keywords: ambiguous sentence, students'ability, website

\begin{abstract}
ABSTRAK
Artikel menganalisis jenis ambiguity yang paling banyak ditemukan di website dan mencari tahu kemungkinan arti kalimat tersebut. Data diambil dari situs web kaskus dan Facebook. Penelitian dilakukan dengan cara pemberian tes untuk mengetahui apakah mahasiswa dapat mengenali kalimat ambigu. Hasil menunjukkan bahwa dari 13 kalimat ditemukan 12 kalimat dengan lexical ambiguity dan 1 kalimat mungkin mengandung structural ambiguity jika kalimat tersebut tidak lengkap. Berdasarkan dari hasil analisis, dapat disimpulkan bahwa cukup banyak orang yang tidak menyadari pentingnya mempertimbangkan ambigu dalam membuat kalimat sehingga kalimat yang diucapkan dapat memiliki lebih dari satu arti.
\end{abstract}

Kata kunci: kalimat ambigu, kemampuan mahasiswa, website 


\section{INTRODUCTION}

Internet is a medium that can connect people to the world. There are many websites providing forum and chatting tools, for example www.kaskus.us and www.facebook.com. Kaskus and Facebook are two websites which many people use to gain and give information. Sometimes, people who give information are not aware about the meaning of their written sentences or even words. The sentences could have one meaning or more and if there are more than one meaning, it could cause ambiguity. The short meaning of ambiguity is having more than one meaning. Hurford and Heasley (1983) said a word or sentence is ambiguous if it has two (or more) meanings. An example of ambiguity in a sentence is the chicken is ready to eat. There are two meanings, the first one is that the chicken is already cooked and people are going to eat that chicken, the other meaning is a chicken is going to eat.

In an aspect of ambiguity, there are two kinds of ambiguity: structural (grammatical) and lexical ambiguity. Hurford and Heasley (1983) also stated that structural ambiguity is a sentence which is ambiguous because its words related to each other in different ways, though none of the individual words are ambiguous, the whole meaning may create confusion. This article would analyze the ambiguity in the sentences written in the internet. Basically this analysis would try to find out the kinds of ambiguity used by the people writing in kaukus and whether students who have learned syntax and semantics would notice the ambiguity of a sentence or not.

\section{METHODS}

Data were taken in the form of sentences and collected from internet (www.kaskus.us and www.facebook.com). Ambiguous sentences from www.kaskus.us and www.facebook.com were taken and then analyzed based on the theory of ambiguity. Then the ambiguous sentences and phrases were given to the $8^{\text {th }}$ semester students or above who had already learned syntax and semantics that had a relation with meaning and structure to find out their ability to notice an ambiguous sentence.

The main theories used in this paper would be meaning and ambiguity.

Hurford and Heasley (1983: 3) divided two kinds of meaning into speaker meaning which is what a speaker means when he uses a piece of language and sentence meaning which is what a sentence or word means. He gave an example, as follows:

Husband: 'When I go away next week, I'm taking the car'

Wife: 'Oh. Are you? I need the car here to take the kids to school'

(Hurford \& Heasley, 1983: 5)

In the conversation above when the wife in the above exchange says 'Are you?' she is taking up a position opposed to her husband. Sentence meaning can be seen when someone says, 'Can you pass the salt?' In this case, actually he asks about his hearer's ability to pass the salt, but requesting the hearer to pass the salt.

From the examples above it is clear that between speaker meaning and sentence meaning, a sentence or word could have more than one meaning. If the sentence has more than one meaning, it could cause an ambiguity. Ambiguity is defined as a word having two or more synonyms (Hurford and Heasley 1983: 122). Chafe (1970: 77) and Cann (1993: 8) have the same opinion that that ambiguity is two or more utterances differ semantically but not phonetically, in short ambiguity shows more than one meaning. 
Hurford and Heasley divided two kinds of ambiguity into lexical ambiguity and structural ambiguity. Hurford and Heasley (1983: 126) stated that there are four suggested statements of the relationship between ambiguous sentences and ambiguous words.

Table 1 Four Suggested Statements of the Relationship between Ambiguous Sentences

\begin{tabular}{ll}
\hline Statement A & $\begin{array}{l}\text { All sentences which contain one or more ambiguous words are } \\
\text { ambiguous, and every sentence which contains no ambiguous } \\
\text { words is unambiguous. }\end{array}$ \\
Statement B & $\begin{array}{l}\text { Some sentences which contain ambiguous words are } \\
\text { ambiguous while others are not, and some sentences which } \\
\text { contain no ambiguous words are ambiguous while others are } \\
\text { not. } \\
\text { Statement C }\end{array}$ \\
$\begin{array}{l}\text { Some sentences which contain ambiguous words are } \\
\text { ambiguous while some are not, but all sentences which contain } \\
\text { no ambiguous words are unambiguous. }\end{array}$ \\
$\begin{array}{l}\text { All sentences which contain ambiguous words are ambiguous, } \\
\text { but some sentences which contain no ambiguous words are also } \\
\text { ambiguous while others are not. }\end{array}$ \\
\hline
\end{tabular}

(Source : Hurford \& Heasley 1983)

Berry, Kamsties, and Krieger (2003: 10) pointed out that lexical ambiguity occurs when a word has several meanings. The causes of lexical ambiguity according to Hurford \& Heasley (1983: 128) is the ambiguous word. Two types of ambiguity are homonymy and polysemy.

Homonymy as defined by Allan (1986: 147) is, "The relation between two or more expressions which has the same form but different meaning," expression here means the words and the same form means that the words are written identically. Perhaps a definition from Simpson (1981: 179) will give clearer understanding, that is, "Homonyms are two different words (i.e. vocabulary items) which are written identically and sound identical, e.g. bear (both beast and verb)." This means that words that have the similarity in written and pronunciation but differ in meaning is called Homonymy.

Hurford and Heasley (1983) and Finegan (1999: 198) differentiate homonymy and polysemy by seeing the relationship between the two senses. In homonymy the senses has no relationship from one another but in polysemy, the senses have a Example of the word with no related senses.

Simpson (1981: 179) supported this by saying that polysemy is a word that has two or more meanings for example the word 'mode' can be 'way', 'fashion'.

Hurford and Heasly (1983) gives an example as follows,

The word "Fork" has more than one meaning with related senses.

- $\quad$ Fork (noun) it means a tool with a handle and three or four sharp points used for eating food

- Fork (noun) it means a garden tool with a long or short handle and three or four sharp metal points used for digging.

Structural ambiguity occurs when the different meaning is caused by the grammatical items instead of by lexical or the meaning of the words. Hurford and Heasley give this example (1983: 128) old man and woman. The first meaning is only men who are old but not the women [oldmen] and women. 


\section{RESULTS AND DISCUSSIONS}

The data are in the forms of sentences and questions are used by the people in chatting in Kaskus (www.kaskus.us) and Facebook (www.facebook.com). The two websites are selected because there are many people using those websites to communicate or to gain information of today's news. From the two websites, 13 sentences/phrases are chosen. They are as follows:

1. Want to write something to make money, but has no idea..(www.facebook.com)

2. Change a letter (http://www.kaskus.us/showthread.php?t=2036007)

3. To the ocean of dream...(www.facebook.com)

4. Having dinner at shin men... what a cold nite...(www.facebook.com)

5. My purple ankle boots has landed at my house today (www.facebook.com)

6. Ah.. the final day... will miss this place (www.facebook.com)

7. ...I'm getting a hang of this (www.facebook.com)

8. It's over... (www.facebook.com)

9. Damn she's hot (www.facebook.com)

10. I've been thinking about what is this all about, you put a fire on me, let's see your best shot! (www.facebook.com)

11. I'm sorry baby for the picture of you that I've been create... (www.facebook.com)

12. I'm in the wrong track then... (www.facebook.com)

13. Time to make some money (www.facebook.com)

All those data will be classified into their kinds whether they are lexically or structurally ambiguous. Then the students ability to notice will also be noted.

\section{Analysis of the Ambiguous Sentences} later.

In this part, there are some examples of analyzing the data then the summary will be described

\section{Sentence 1}

- Want to write something to make money, but has no idea..

This sentence is structurally ambiguous if the sentence don't have "but has no idea" phrase. However, this sentence is not ambiguous.

The meanings if the sentence do not have "but has no idea" are:

Meaning 1 want to write the words "something to make money"

The structure:

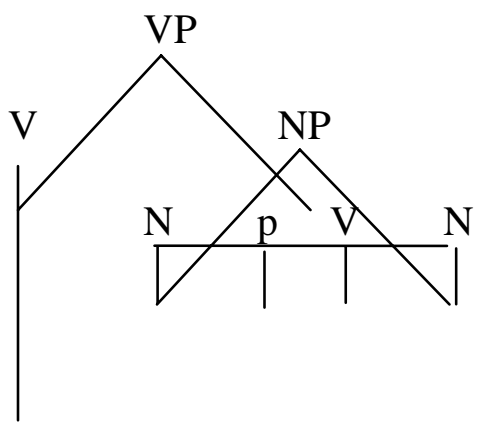

...write something to make money 
Meaning 2 want to earn money by writing something.

The structure:

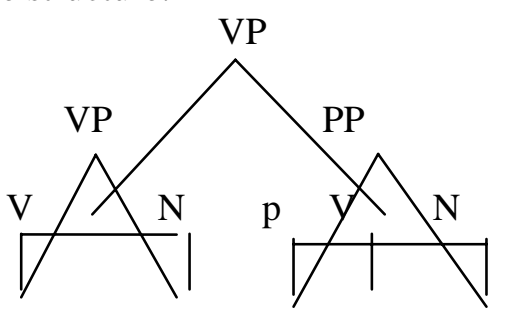

...write something to make money

Sentence 2

- Change a letter

Both the words "change" and "letter" carried a lexical ambiguity. According to Oxford Advanced Learner Dictionary $7^{\text {th }}$ edition (1995: 233) and (1995: 847), both the word "change" and "letter" have more than one meaning.

The meaning of word "change" here is:

- Change (verb) it means Become or make sb/sth different

- Change (verb) it means Replace one thing or person with another

- Change (verb) it means Take off your clothes and put others on

- Change (verb) it means Give and receive money in exchange for money of smaller value or in a foreign currency

The meaning of word "letter" here is:

- Letter (noun) it means A message that is written down or printed on paper and usually put in an envelope and sent to somebody

- Letter (noun) it means A written or printed sign representing a sound used in speech (alphabet)

The meaning of the sentence change a letter could have more than one meaning:

1. To make a different written message

2. To make a different alphabet

3. To replace the written message

4. To replace the alphabet

Both the word "change" and "letter" is polysemy because it has more than one meaning with related sense which is the sense of the act of replacing something and the sense of a tool for communication.

Sentence 3

- $\quad$ To the ocean of dream.....

The word "dream" carried a lexical ambiguity. According to Oxford Advanced Learner Dictionary (1995: 446), the word "dream” carries more than one meaning.

The meaning of word "dream" here is:

- Dream (noun) it means series of images and events that happen in your mind while you are asleep

- Dream (noun) it means wish to have or be sth, especially one that seems difficult to achieve

The sentence of to the ocean of dream contains more than one meaning:

1. Someone is going to the ocean where s/he saw in their mind while they are sleeping.

2. Someone is going to the ocean that s/he really wants to go. 
The word "dream" is homonymy because the meaning of word "dream" has more than one meaning with no related sense which is the $1^{\text {st }}$ is sense of visual images and $2^{\text {nd }}$ is the sense of someone desire.

\section{Sentence 4}

- Having dinner at Shin Men... what a cold night

The word "cold" carried a lexical ambiguity. According to Oxford Advanced Learner Dictionary (1995: 277), the word "cold” carry more than one meaning

The meaning of word "Cold" is:

- $\quad$ Cold (adjective) it means Having a lower than usual temperature

- $\quad$ Cold (adjective) it means Without emotion, unfriendly

- $\quad$ Cold (noun) it means common illness of the nose or throat

The sentence of what a cold night contains more than one meaning:

1. The night which is low in temperature

2. The night when s/he got a bad luck

The word "cold" is homonymy because the meaning of word "cold" has more than one meaning with no related sense which is the $1^{\text {st }}$ sense is the sense of temperature and the $2^{\text {nd }}$ sense is the sense of feeling.

Sentence 5

- My purple ankle boots has landed at my house today

The word "landed" carried a lexical ambiguity. According to Oxford Advanced Learner Dictionary (1995: 827), the word "land" contains more than one meaning.

The meaning of the word "land" here is

- $\quad$ Land (noun) it means solid dry part of the earth surface, area of ground used for farming, etc

- $\quad$ Land (verb) it means come down through the air onto the ground, reach a final position.

The sentence My purple ankle boots has landed at my house today have more than one meaning:

1. Somebody purple boots is falling to the ground at his/her house today.

2. Somebody has received his/her ankle boots arrived at his/her house today.

The word "landed" is homonymy because it has more than one meaning with no related sense which is the $1^{\text {st }}$ sense is the sense of a place and the $2^{\text {nd }}$ sense is the sense of action.

Sentence 6

- $\quad$ Ah.. The final day... will miss this place.

The word "final" and "miss" both carried a lexical ambiguity according to Oxford Advanced Learner Dictionary, "final” (1995: 551) and "miss" (1995: 939) have more than one meaning

The meaning of the word "final" here is:

- $\quad$ Final (adjective) it means being or happening at the end of a series or events

- $\quad$ Final (noun) it means last of a series of competitions

The meaning of the word "miss" here is:

- Miss (verb) it means fail to hit, catch, or reach

- $\quad$ Miss (verb) it means feel sad because of the absence of somebody/something 
The sentence of ah..the final day...will miss the place has more than one meaning :

1. Someone wants to watch the last series of competition but couldn't get to the place.

2. Someone wants to watch the last series of competition and will feel sad about the last competition.

3. Someone is going to have his/her last day somewhere and try to reach the place but couldn't.

4. Someone is going to have his/her last day somewhere and will feel sad if he think about that place.

The word "final" is polysemy because it has more than one meaning with related sense which is the sense of time. While the word "miss" is homonymy because it has more than one meaning with no related senses which is the $1^{\text {st }}$ is the sense of a failed action, and the $2^{\text {nd }}$ sense is the sense of feeling.

Sentence 7

- $\quad$.......i'm getting a hang of this.

The word "hang" carried a lexical ambiguity. According to Oxford Advanced Learner Dictionary (1995: 676), the word "hang” has more than one meaning

The meaning of the word "hang" here is:

- Hang (verb) it means attach sth or be attached at the top so that lower part is free or loose

- Hang (noun) it means understand something or learn how to do something

The sentence I'm getting a hang of this is not ambiguous because there is a preposition "a" before the word "hang".

The word "hang" is polysemy because it has more than one meaning with related sense which is the sense of action.

\section{Sentence 8}

- It's over...

The word "over" carried a lexical ambiguity. According to Oxford Advanced Learner Dictionary $7^{\text {th }}$ edition (1995: 1038), the word “over” has more than one meaning.

The meaning of word "over" here is:

- Over (adverb) it means Downwards and away from a vertical position, From one side to another side, Across a street, an open space, etc

- Over (adverb) it means ended

The sentence it's over. What you do today is for tomorrow's good has more than one meaning:

1. Someone is saying that something is going from one side to another side.

2. Someone is saying that something is already ended.

The word "over" is homonymy because it has more than one meaning with no related sense which is the $1^{\text {st }}$ sense is the sense of vision and the $2^{\text {nd }}$ sense is the sense of activity.

\section{Possible Meaning from Sentences and Phrases}

Based on the first analysis, the summary of the meaning of the data will be presented below together with the meaning. This data and the meaning will be given to the students as a test. 
Table 2 The Possible Meaning from the Sentences

\begin{tabular}{|c|c|}
\hline Sentences or phrase & Meaning \\
\hline $\begin{array}{l}\text { Want to write something } \\
\text { to make money, but has } \\
\text { no idea }\end{array}$ & $\begin{array}{l}\text {-want to write the words "something to make money" } \\
\text {-want to earn money by writing something }\end{array}$ \\
\hline 2. Change a letter & $\begin{array}{l}\text {-To make a different written message } \\
\text {-To make a different alphabet } \\
\text {-To replace the written message } \\
\text {-To replace the alphabet }\end{array}$ \\
\hline 3. To the ocean of dream... & $\begin{array}{l}\text {-Someone is going to the ocean where s/he saw in their mind while they are } \\
\text { sleeping. } \\
\text {-Someone is going to the ocean that s/he really wants to go }\end{array}$ \\
\hline $\begin{array}{l}\text { 4. Having dinner at shin } \\
\text { men... what a cold nite... }\end{array}$ & $\begin{array}{l}\text {-the night when s/he had a dinner at ShinMen is low temperature } \\
\text {-Someone got a bad luck at the night when s/he had a dinner at ShinMen }\end{array}$ \\
\hline $\begin{array}{l}\text { 5. My purple ankle boots } \\
\text { has landed at my house } \\
\text { today }\end{array}$ & $\begin{array}{l}\text {-Somebody purple boots is falling to the ground at his/her house today. } \\
\text {-Somebody has received his/her ankle boots arrived at his/her house today }\end{array}$ \\
\hline $\begin{array}{l}\text { 6. Ah.. the final day... will } \\
\text { miss this place }\end{array}$ & $\begin{array}{l}\text {-Someone wants to watch the last series of competition but couldn't get to the } \\
\text { place. } \\
\text {-Someone wants to watch the last series of competition and will feel sad about } \\
\text { the last competition. } \\
\text {-Someone is going to have his/her last day somewhere and try to reach the place } \\
\text { but couldn't. } \\
\text {-Someone is going to have his/her last day somewhere and will feel sad if he } \\
\text { think about that place. }\end{array}$ \\
\hline $\begin{array}{l}\text { 7. life is good..I'm getting a } \\
\text { hang of this }\end{array}$ & $\begin{array}{l}\text {-Someone is attaching something on the top. } \\
\text {-Someone is learning how to do something and become used to it }\end{array}$ \\
\hline $\begin{array}{l}\text { 8. It's over. What you do } \\
\text { today is for tomorrow's } \\
\text { good }\end{array}$ & $\begin{array}{l}\text {-Someone is saying that something is going from one side to another side. } \\
\text {-Someone is saying that something is already ended }\end{array}$ \\
\hline 9. Damn she's hot & $\begin{array}{l}\text {-She is having a high temperature } \\
\text {-She is eating something that make her feel burn in her mouth } \\
\text {-She is popular } \\
\text {-She is angry } \\
\text {-She is sexy }\end{array}$ \\
\hline $\begin{array}{l}\text { 10. I've been thinking about } \\
\text { what is this all about, you } \\
\text { put a fire on me, let's see } \\
\text { your best shot! }\end{array}$ & $\begin{array}{l}\text {-Someone is thinking about a person who burn him/her and waiting for the gun } \\
\text { shot } \\
\text {-Someone is thinking about a person who make his/her enthusiast and waiting } \\
\text { for the gun to shot } \\
\text {-Someone is thinking about a person who burn him/her and want to see the best } \\
\text { job } \\
\text {-Someone is thinking about a person who make him/her enthusiast and want to } \\
\text { see their best try }\end{array}$ \\
\hline $\begin{array}{l}\text { 11. I'm sorry baby for the } \\
\text { picture of you that I've } \\
\text { been create... }\end{array}$ & $\begin{array}{l}\text {-Apologizing someone because drawing a picture of his/her } \\
\text {-Apologizing someone because creating his/her picture using her photo } \\
\text {-Apologizing someone because creating a description from his/her mind. } \\
\text {-Apologizing someone because s/he make an image of someone from his/her } \\
\text { memory }\end{array}$ \\
\hline $\begin{array}{l}\text { 12. I'm in the wrong track } \\
\text { then... }\end{array}$ & $\begin{array}{l}\text {-Someone is walking in the wrong rough or road } \\
\text {-Someone is following a wrong marks left by someone } \\
\text {-Someone is taking a wrong path or course } \\
\text {-Someone is playing a wrong music }\end{array}$ \\
\hline $\begin{array}{l}\text { 13. Time to make some } \\
\text { money }\end{array}$ & $\begin{array}{l}\text {-Time to create the thing which is money } \\
\text {-Time to earn some money }\end{array}$ \\
\hline
\end{tabular}




\section{Most Frequently Appeared Ambiguity}

From Table 2 it is found out that from the 13 ambiguous sentences or phrases, there are 12 sentences with Lexical ambiguity and 1 sentence with Structural ambiguity. 12 sentences with lexical ambiguity are divided to 4 sentences containing polysemy, 7 sentences containing homonymy and 1 sentence containing both polysemy and homonymy. The table of the result is:

Table 3 The Result of Analysis

\begin{tabular}{|c|c|c|c|c|}
\hline \multirow{2}{*}{\multicolumn{2}{|c|}{ Sentences or phrase }} & \multicolumn{2}{|c|}{ Lexical } & \multirow{3}{*}{$\begin{array}{l}\text { Structural } \\
-\end{array}$} \\
\hline & & \multirow{2}{*}{$\begin{array}{l}\text { homonymy } \\
\text { - }\end{array}$} & \multirow{2}{*}{$\begin{array}{l}\text { polysemy } \\
-\end{array}$} & \\
\hline 1. & Want to write something to make money & & & \\
\hline 2. & Change a letter & & $\mathrm{v}$ & \\
\hline 3. & To the ocean of dream... & $\mathrm{v}$ & & \\
\hline 4. & Having dinner at shin men... what a cold nite... & $\mathrm{v}$ & & \\
\hline $\begin{array}{l}5 . \\
6 .\end{array}$ & $\begin{array}{l}\text { Mv nurnle ankle honts has landed at mv house todav } \\
\text { Ah.. the final day... will miss this place }\end{array}$ & $\begin{array}{l}\mathrm{v} \\
\mathrm{v} \text { (miss) }\end{array}$ & v (final) & \\
\hline 7. & life is good..I'm getting a hang of this & & $\mathrm{v}$ & \\
\hline 8. & It's over. What you do today is for tomorrow's good & $\mathrm{v}$ & & \\
\hline 9. & Damn she's hot & $\mathrm{v}$ & & \\
\hline 10. & $\begin{array}{l}\text { I've been thinking about what is this all about, you put a fire on } \\
\text { me, let's see your best shot! }\end{array}$ & $\mathrm{v}$ & & \\
\hline 11. & I'm sorry baby for the picture of you that I've been create... & & $\mathrm{v}$ & \\
\hline 12 & I'm in the wrono trark then & $\mathrm{v}$ & & \\
\hline 13. & Time to make some money & & $\mathrm{v}$ & \\
\hline
\end{tabular}

\section{Student Data Analysis}

The test given to the students will be based on the interpretation of the 13 sentences. Students are supposed to find out In this part, sudents are supposed to notice whether the sentence is ambiguous or not by analyzing the questionnaire.

\section{Question 1:}

- Want to write something to make money, but has no idea...

a. want to write the words "something to make money"

b. want to earn money by writing something

c. all possible

Table 4 Percentage of Question 1

\begin{tabular}{|c|c|c|}
\hline Answer & $\begin{array}{c}\text { Number of } \\
\text { respondents }\end{array}$ & Percentage \\
\hline A & 1 & $5 \%$ \\
\hline B & 2 & $10 \%$ \\
\hline C & 2 & $10 \%$ \\
\hline D & 10 & $50 \%$ \\
\hline E & 5 & $25 \%$ \\
\hline \multicolumn{3}{|l}{} \\
\hline
\end{tabular}

The percentage of answer $\mathrm{A}=10 \%, \mathrm{~B}=50 \%$, and $\mathrm{C}=40 \%$. The biggest percentage is $\mathrm{B}$ which is "want to earn money by writing something". This sentence is not structurally ambiguous and most of the respondents answered $\mathrm{B}$. This maybe happened because people usually read and interpret the meaning of a sentence only in one structure. 


\section{Question 2:}

- Change a letter

a. To make a different written message

b. To make a different alphabet

c. To replace the written message

d. To replace the alphabet

e. all possible

Table 5 Percentage of Question 2

\begin{tabular}{|c|c|c|}
\hline Answet & $\begin{array}{c}\text { Number of } \\
\text { respondents }\end{array}$ & Percentage \\
\hline A & 1 & $5 \%$ \\
\hline B & 2 & $10 \%$ \\
\hline C & 2 & $10 \%$ \\
\hline D & 10 & $50 \%$ \\
\hline E & 5 & $25 \%$ \\
\hline \multicolumn{3}{|l}{} \\
\hline
\end{tabular}

The percentage of answer $\mathrm{A}=5 \%, \mathrm{~B}=10 \%, \mathrm{C}=10 \% \mathrm{D}=50 \%$, and $\mathrm{E}=25 \%$. The biggest percentage is D which is "to replace an alphabet". In this sentence, 5 respondents (25\%) notice that this sentence is ambiguous. Most of the respondent answered D could be because the sentence is mostly used in daily conversation and no one will think this as an ambiguous sentence.

\section{Question 3:}

- To the ocean of dream...

a. Someone is going to the ocean where s/he saw in their mind while they are sleeping.

$b$. Someone is going to the ocean that s/he really wants to go

c. All possible

Table 6 Percentage of Question 3

\begin{tabular}{|c|c|c|}
\hline Answet & $\begin{array}{c}\text { Number of } \\
\text { respondents }\end{array}$ & Percentage \\
\hline A & 0 & $0 \%$ \\
\hline B & 17 & $85 \%$ \\
\hline C & 3 & $15 \%$ \\
\hline \multicolumn{3}{|l}{} \\
\hline
\end{tabular}

The percentage of answer $\mathrm{A}=0 \%, \mathrm{~B}=85 \%$, and $\mathrm{C}=15 \%$. The biggest percentage is $\mathrm{B}$ which is "someone is going to the ocean that s/he really wants to go". In this sentence, only 3 respondents (15\%) notice that this sentence is ambiguous. Most of the respondents answer B could be because the word "dream" usually interpreted as desire.

\section{Question 4:}

- Having dinner at shin men... what a cold nite...

a. the night when s/he had a dinner at ShinMen is low temperature

b. Someone got a bad luck at the night when s/he had a dinner at ShinMen

c. All possible 
Table 7 Percentage of Question 4

\begin{tabular}{|c|c|c|}
\hline Answer & $\begin{array}{c}\text { Number of } \\
\text { respondents }\end{array}$ & Percentage \\
\hline A & 14 & $70 \%$ \\
\hline B & 4 & $20 \%$ \\
\hline C & 2 & $10 \%$ \\
\hline \multicolumn{3}{|l}{} \\
\hline
\end{tabular}

The percentage of answer $\mathrm{A}=70 \%, \mathrm{~B}=20 \%$ and $\mathrm{C}=10 \%$. The biggest percentage is A which is "the night when s/he had a dinner at ShinMen is low temperature". In this sentence, only 2 respondents (10\%) are able to notice that this sentence is ambiguous. Most of the respondents interpret cold as low temperature because it is also often used in daily conversation.

\section{Question 5:}

- $\quad$ My purple ankle boots has landed at my house today

a. Somebody purple boots is falling to the ground at his/her house today.

b. Somebody has received his/her ankle boots arrived at his/her house today

c. All possible

Table 8 Pewrcentage of Question 5

\begin{tabular}{|c|c|c|}
\hline Answet & $\begin{array}{c}\text { Number of } \\
\text { respondents }\end{array}$ & Percentage \\
\hline A & 0 & $0 \%$ \\
\hline B & 19 & $95 \%$ \\
\hline C & 1 & $5 \%$ \\
\hline \multicolumn{3}{|l}{} \\
\hline
\end{tabular}

The percentage of answer $\mathrm{A}=0 \%, \mathrm{~B}=95 \%$, and $\mathrm{C}=5 \%$. The biggest percentage is $\mathrm{B}$ which is "Somebody has received his/her ankle boots arrived at his/her house today". There is only one respondent (5\%) who is able to notice that this sentence is ambiguous. Most of the respondents interpret it as arrived could be because whether the word landed is ambiguous, but the whole sentence make it unambiguous.

\section{Question 6:}

- $\quad$ Ah.. the final day... will miss this place

a. Someone wants to watch the last series of competition but couldn't get to the place.

$b$. Someone wants to watch the last series of competition and will feel sad about the last competition.

c. Someone is going to have his/her last day somewhere and try to reach the place but couldn't.

$d$. Someone is going to have his/her last day somewhere and will feel sad if he think about that place.

e. All possible

Table 9 Percentage of Question 6

\begin{tabular}{|c|c|c|}
\hline Answet & $\begin{array}{c}\text { Number of } \\
\text { respondents }\end{array}$ & Percentage \\
\hline A & 3 & $15 \%$ \\
\hline B & 0 & $0 \%$ \\
\hline C & 0 & $0 \%$ \\
\hline D & 14 & $70 \%$ \\
\hline E & 3 & $15 \%$ \\
\hline \multicolumn{3}{|l}{} \\
\hline
\end{tabular}


The percentage of answer $\mathrm{A}=15 \%, \mathrm{~B}=0 \%, \mathrm{C}=0 \%, \mathrm{D}=70 \%$, and $\mathrm{E}=15 \%$. The biggest percentage is D which is "Someone is going to have his/her last day somewhere and will feel sad if he think about that place". In this sentence, 3 respondents (15\%) could be able to notice that this sentence is ambiguous. Most of the respondents answer $\mathrm{D}$ because it is commonly used in the daily conversation. Even if the sentence is out of context, they also interpret it only in one meaning.

\section{Question 7:}

- I'm getting a hang of this

a. Someone is attaching something on the top.

$b$. Someone is learning how to do something and become used to it

c. All possible

Table 10 Percentage of Question 7

\begin{tabular}{|c|c|c|}
\hline Answer & $\begin{array}{c}\text { Number of } \\
\text { respondents }\end{array}$ & Percentage \\
\hline A & 0 & $0 \%$ \\
\hline B & 17 & $85 \%$ \\
\hline C & 3 & $15 \%$ \\
\hline \multicolumn{3}{|l}{} \\
\hline
\end{tabular}

The percentage of answer $\mathrm{A}=0 \%, \mathrm{~B}=85 \%$, and $\mathrm{C}=15 \%$. The biggest percentage is $\mathrm{B}$ which is "Someone is learning how to do something and become used to it". This sentence is not ambiguous because it has preposition "a" before the word "hang" and most of respondents interpret the word "hang" as learning how to do something because that word is used often in daily conversation and usually interpret as become used to it.

\section{Question 8:}

- It's over....

a. Someone is saying that something is going from one side to another side.

b. Someone is saying that something is already ended

c. All possible

Table 11 Percentage of Question 8

\begin{tabular}{|c|c|c|}
\hline Answer & $\begin{array}{c}\text { Number of } \\
\text { respondents }\end{array}$ & Percentage \\
\hline A & 0 & $0 \%$ \\
\hline B & 19 & $95 \%$ \\
\hline C & 1 & $5 \%$ \\
\hline \multicolumn{3}{|l}{} \\
\hline
\end{tabular}

The percentage of answer $\mathrm{A}=0 \%, \mathrm{~B}=95 \%$ and $\mathrm{C}=5 \%$. The biggest percentage is $\mathrm{B}$ which is "Someone is saying that something is already ended". Most of the respondents answer B and only 1 respondent answer C. It could be because the word "over" used often in daily conversation and usually interpreted as something is ended.

\section{The Result of Student Analysis}

From the data below it can be seen that sentences which students could not notice the sentence is ambiguous are sentences number 5 and 8 in which only 1 respondent (5\%) chooses that all answers are possible. Sentence number 6 is "My purple ankle boots has landed at my house today" and most of 
the respondents interpret it as somebody has received his/her ankle boots arrived at his/her house today. Sentence number 9 is "It's over" and most of the respondents interpret it as someone is saying that something is already ended. Most of the respondents misinterpreted those sentences maybe because the sentences are uses in daily conversation and although the word is ambiguous, but the whole sentence makes it looks unambiguous.

While the sentences which students could notice to be ambiguous is sentence number 9 in which 8 respondents (40\%) choose all answers are possible (the possibility of answer could be seen in Table 11. Sentence number 9 is "Damn she's hot". In that sentence, 3 respondents interpret as She is having a high temperature, 1 respondent interpret as she is popular, 8 respondents interpret it as she is sexy. Most of respondents choose that all answers are possible maybe because the sentences are not having any clear contexts.

The result of the questionnaire could be seen in Table 14

Table 14 Result of the Questionnaire

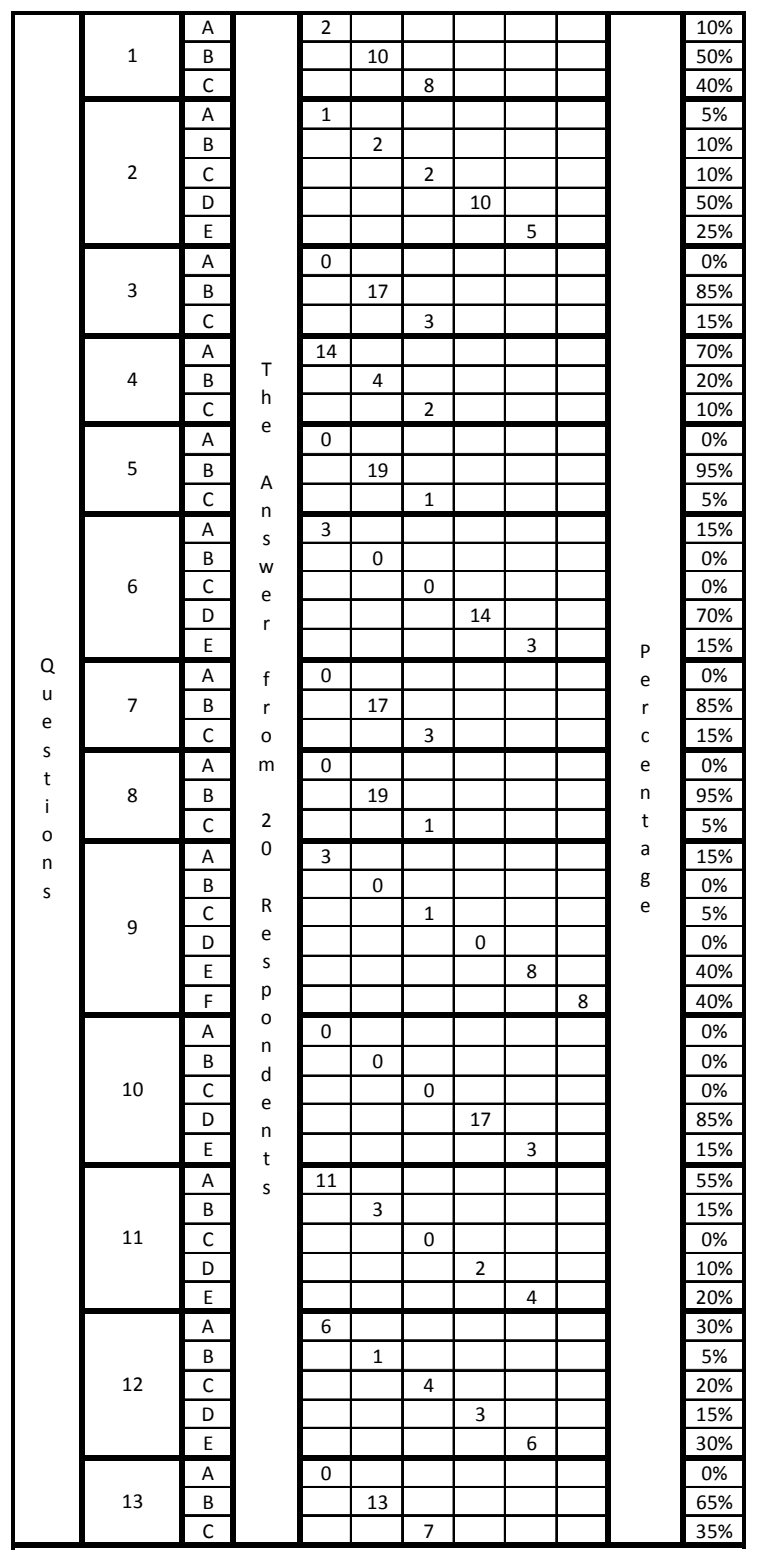




\section{CONCLUSION}

Kaskus and Facebook are now popular in Jakarta or maybe in Indonesia. They could give much information to the people who read those websites. But somehow, people who give information and statement do not care about the meaning in those sentences or statements they have made so it could cause an ambiguity. The readers also sometimes do not realize that the sentence or statement is ambiguous. Ambiguity occurs when a word or sentence has two or more perception of meanings; for a word ambiguity it is called lexical ambiguity and for a sentence ambiguity it is called structural (grammatical) ambiguity. In this paper, it is concluded that the most frequent appeared ambiguity in those websites is lexical ambiguity, as, from 13 sentences or phrases found, 12 sentences are lexically ambiguous and 1 sentence is not ambiguous. 12 sentences with lexical ambiguity are divided to 4 sentences contain polysemy, 7 sentences contain homonymy and 1 sentence contains both polysemy and homonymy. For this analysis, it can also be concluded that students having learned semantics, syntax and meaning somehow do not always realize that a sentence or word could have more than one meaning. It is proven by the data that has been analyzed where the biggest percentage of people who answer all sentences possible is only $40 \%$. This may happen because most of the students do not always pay attention to the possibilities of ambiguity in a sentence. The students directly interpret the meaning without considering the possible context.

\section{REFERENCES}

Allan, K. (1986). Linguistic Meaning. London: Routledge \& Kegan Paul.

Berry, D. M. , Kamsties, E. , Krieger, M.M. (2003). From Contract Drafting to Software Spesification : Linguistic Source of Ambiguity (Electronic version).

Los Angeles: http://se.uwaterloo.ca/ dberry/handbook/ambiguityHandbook.pdf.

Cann, R. (1993). Formal Semantics. Cambridge: Cambridge University Press.

Chafe, W. L. (1970). Meaning and the Structure of Language. Chicago: NTC Publishing Group.

Finegan, E. (1999). Language: its Structure and Use ( $3^{\text {rd }}$ ed). United States of America: Harcourt Brace College Publishers.

Hurford, J. R., \& Heasley, B. (1983). Semantics a Coursebook. Cambridge: Cambridge University Press.

Oxford Advanced Learner's Dictionary.(1995). Oxford: Oxford University Press.

Simpson, J.M.Y. (1981). A First Course in Linguistics. Edinburgh: Edinburgh University Press. 